\title{
Urban soil microbial community and microbial-related carbon storage are severely limited by sealing
}

\author{
Marlon Correa Pereira ${ }^{1,2}$ (D) $\cdot$ Roisin O'Riordan $^{2}$ (I) $\cdot$ Carly Stevens $^{2}$ (D)
}

Received: 22 September 2020 / Accepted: 17 January 2021 / Published online: 29 January 2021

(C) The Author(s) 2021

\begin{abstract}
Purpose Urbanisation causes changes in land use, from natural or rural to urban, leading to the sealing of soil and the replacement of vegetation by buildings, roads and pavements. The sealing process impacts soil properties and services and can lead to negative consequences for microbial attributes and processes in soil. At present, information about the microbial community following soil sealing is limited. As such, we investigated how changes in soil physical and chemical properties caused by sealing affect the soil microbial community and soil ecosystem services.

Material and methods Soils were sampled beneath impervious pavements (sealed) and from adjacent pervious greenspace areas (unsealed). Soil properties (total C, total N, C:N ratio and water content) and microbial attributes (microbial biomass C, Nmineralisation and phospholipid fatty acids-PLFA) were measured and correlated.

Results and discussion A reduction of total $\mathrm{C}$, total $\mathrm{N}$, and water content were observed in sealed soil, whilst the C:N ratio increased. Sealed soil also presented a reduction in microbial attributes, with low $\mathrm{N}$-mineralisation revealing suppressed microbial activity. PLFA data presented positive correlations with total $\mathrm{C}$, total $\mathrm{N}$ and water content, suggesting that the microbial community may be reduced in sealed soil as a response to soil properties. Furthermore, fungal:bacterial and gram-positive:gram-negative bacterial ratios were lower in sealed soil indicating degradation in $\mathrm{C}$ sequestration and a consequential effect on $\mathrm{C}$ storage.

Conclusions Sealing causes notable changes in soil properties leading to subsequent impacts upon the microbial community and the reduction of microbial activity and soil $\mathrm{C}$ storage potential.
\end{abstract}

Keywords Urban soil $\cdot$ Soil sealing $\cdot$ Impervious surfaces $\cdot$ Microbial biomass $\cdot \mathrm{N}$-mineralisation $\cdot$ PLFA $\cdot$ Soil carbon $\cdot$ Carbon storage

\section{Introduction}

Urbanisation causes considerable impacts on soil properties and services (Yan et al. 2015, 2016). Changes in land use from natural and rural to urban are associated with the replacement of vegetation by buildings, roads and pavements (Edmondson et al. 2012; Yan et al. 2016). The high degree of impermeable

Responsible editor: Hang-Wei Hu

Marlon Correa Pereira marlon.pereira@ufv.br

1 Biological Science and Health Institute, Universidade Federal de Viçosa - Campus Rio Paranaíba, MG-230 Km 7, Zona Rural, Rio Paranaiba, MG 38810-000, Brazil

2 Lancaster Environment Centre, Lancaster University, Lancaster LA1 4YQ, UK surfaces in cities has many negative consequences for the environment and the services it provides, particularly those provided by soil (Morgenroth et al. 2013; Wei et al. 2013; Piotrowska-Długosz and Charzyński 2015; Ziter and Turner 2018; Kelleher et al. 2020).

Carbon (C) storage is an important ecosystem service provide by soil in urban areas, with vegetation biomass inputs and soil organic carbon (SOC) being key components of overall C storage (Edmondson et al. 2012; Ziter and Turner 2018). Soil sealing due to urbanisation leads to the removal of plants and topsoil during the paving and construction process. This results not only in large losses of $\mathrm{C}$ stocks from urban soil (Wei et al. 2014) but also alters soil C dynamics, typically leading to a loss of SOC (Majidzadeh et al. 2018). Previous soil C inventories suggested that urban soil provides very little or no soil $\mathrm{C}$ storage (Bradley et al. 2005). However, more recently, significant amounts of soil $\mathrm{C}$ have been reported in urban areas, in soils of greenspaces and beneath sealed surfaces of pavements and 
houses (Edmondson et al. 2012; Wei et al. 2014; Majidzadeh et al. 2017; Yan et al. 2016; Hu et al. 2018; Vasenev et al. 2018). As such, urban soil $\mathrm{C}$ and the dynamics of $\mathrm{C}$ storage are receiving increasing attention in research literature.

Many other key ecosystem services and soil properties are affected by soil sealing. Water infiltration is prevented or reduced, changing surface runoff patterns and seasonal dynamics of soil water content (Majidzadeh et al. 2018; Hu et al. 2020; Kelleher et al. 2020). Paving materials can act as a reservoir for contaminants such as heavy metals (Hu et al. 2018) and polycyclic aromatic hydrocarbons ( $\mathrm{Li}$ et al. 2020), and soil temperatures can be increased (Chen et al. 2016, 2017). Gas exchange between the soil and atmosphere is reduced which can lead to higher $\mathrm{CO}_{2}$ concentrations in sealed soil and increased $\mathrm{CO}_{2}$ flux rate near pavement edges $(\mathrm{Wu}$ et al. 2016; Fini et al. 2017). Additionally, soil nutrient content can be altered, with sealed soils exhibiting increased calcium, potassium, sodium and phosphorous and decreased aluminium, iron, magnesium and nitrogen (Zhao et al. 2012; Morgenroth et al. 2013; Hu et al. 2018; Majidzadeh et al. 2018). The severe decrease in nitrogen $(\mathrm{N})$ can lead to very high $\mathrm{CN}$ ratios in sealed soils, despite the concurrent loss of soil C (Zhao et al. 2012; Hu et al. 2018).

These changes to the soil environment also affect soil microbes, which may impact the microbial processes and activities that underpin many important soil services (Zhao et al. 2012). Whilst sealed soils remain largely understudied, a small number of studies have observed that sealing can lead to a decrease in microbial biomass $\mathrm{C}$, microbial biomass $\mathrm{N}$, enzyme activities and respiration potential (Zhao et al. 2012; Wei et al. 2013; Piotrowska and Charzynski 2015), as well as a decrease in $\mathrm{N}$-mineralisation potential (Zhao et al. 2012; Majidzadeh et al. 2018). Similarly, sealing has led to changes in bacterial communities, with a reduction in alpha diversity and a distinct community found in sealed soil when compared with unsealed soil (Hu et al. 2018; Yu et al. 2019). Research has shown that sealing has a negative effect on urban soil microbial attributes and bacterial communities, although little is known about the dynamics of both bacterial and fungal communities and their contribution to the soil microbial community in sealed soils. Furthermore, there is a gap in knowledge into what these altered bacterial and fungal dynamics mean for important soil ecosystem services such as nutrient cycling and $\mathrm{C}$ storage within sealed soils. Fungal:bacterial dominance is considered an important factor in C sequestration (Strickland and Rousk 2010), and the ratio between grampositive:gram-negative bacteria provides insight into the stability or recalcitrance of $\mathrm{C}$ in the soil (Fanin et al. 2019). At present, these dynamics have not been studied in sealed soil, and therefore, the implications for soil $\mathrm{C}$ storage across the urban landscape are currently unknown.

In this paper, we investigate how changes to soil physical and chemical properties caused by sealing affect the microbial community and microbial attributes. The city of Lancaster (UK) and surrounding urban areas were used as a study site. We measure the soil properties (total C, total N, C:N ratio and water content) and microbial attributes (microbial biomass $\mathrm{C}$, phospholipid fatty acids and $\mathrm{N}$-mineralisation) to make a comparison across sealed and unsealed soils. To our knowledge, we present the first investigation into bacterial and fungal dynamics in sealed soil using phospholipid fatty acid analysis and consider their contributions to the soil microbial community and consequences for important soil services. We hypothesise that (i) sealing leads to large changes in soil properties, and (ii) sealing leads to changes in microbial attributes, significantly altering community composition and reducing microbial activity. Measurements of soil total C, total N, $\mathrm{C}: \mathrm{N}$ ratio and water content provided indicators of the impacts of sealing on soil properties (hypothesis 1). Microbial biomass $\mathrm{C}$, phospholipid fatty acids and $\mathrm{N}$-mineralisation were used as indicators of changes in microbial attributes, with biomass $\mathrm{C}$ and phospholipid fatty acids pointing to changes in community composition, and $\mathrm{N}$-mineralisation to changes in microbial activity (hypothesis 2).

\section{Materials and methods}

\subsection{Study area}

The study area consisted of the medium-sized UK city of Lancaster and the surrounding urban areas (Fig. 1). The National Soil Map for England and Wales, accessed on the Soilscapes Viewer online (www.landis.org.uk), shows that, across much of Lancaster city, there are freely draining slightly acid loamy soils, whilst sampling sites in the surrounding areas tended to be on slowly permeable seasonally wet acid loamy and clayey soils.

\subsection{Soil sampling}

Sealed soils were collected from 25 roadwork sites where works had exposed the soil beneath pavements and roads. Sealing had occurred at different times in the past, and further research is still needed to determine if the time since sealing has an impact on the measured variables. Soil was collected from the top $10 \mathrm{~cm}$ of soil below the sealed surface and human-made layers. To allow a comparison between soils, an unsealed sample was collected from the nearest available greenspace after each sealed soil. Unsealed samples were collected from the top $10 \mathrm{~cm}$ of soil, primarily from grasscovered road verges, amenity greenspaces and residential gardens, with a distance ranging from 0.5 to $15 \mathrm{~m}$ of the respective sealed site. Approximately $500 \mathrm{~g}$ of both soils (50 samples) were collected with a trowel and were immediately returned to the lab for refrigeration prior to fresh soil tests. 


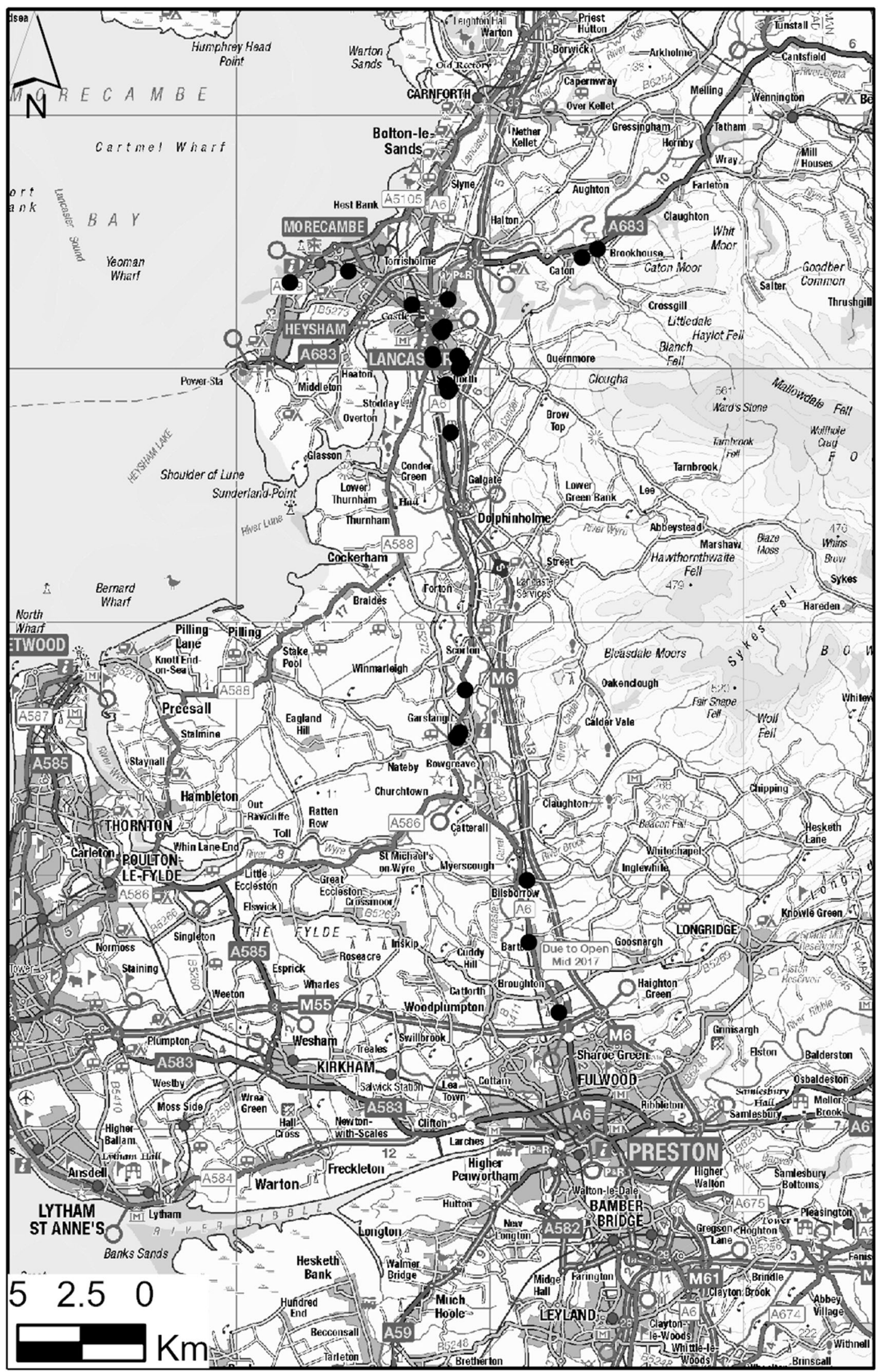

Fig. 1 Location of sampling sites, indicated on the map with black dots 


\subsection{Soil preparation and analysis}

\subsubsection{Soil properties and $\mathrm{CN}$ analysis}

Soil water content was determined gravimetrically by drying the samples at $105{ }^{\circ} \mathrm{C}$ for $24 \mathrm{~h}$. The dried sample was ballmilled to a powder and analysed for total $\mathrm{C}$ and total $\mathrm{N}$ using a dry combustion $\mathrm{CN}$ analyser (vario $\mathrm{Max} \mathrm{CN}$ ).

\subsubsection{Microbial biomass $\mathrm{C}$ and $\mathrm{N}$-mineralisation}

Microbial biomass $\mathrm{C}$ (MBC) was determined using the chloroform fumigation-extraction method (Brookes et al. 1985; Vance et al. 1987). Two subsamples of $5 \mathrm{~g}$ of moisture adjusted soil were prepared for each sample, one fumigated with alcohol-free $\mathrm{CHCl}_{3}$ for $24 \mathrm{~h}$ and one non-fumigated stored at $4{ }^{\circ} \mathrm{C}$. After removal of the $\mathrm{CHCl}_{3}$, both subsamples were extracted with $25 \mathrm{~mL}$ of $\mathrm{K}_{2} \mathrm{SO}_{4}(0.5 \mathrm{M})$ for $30 \mathrm{~min}$. The filtrate was analysed for extracted $\mathrm{C}$ using a TOC analyser (Shimadzu TOC-L $\mathrm{CPN}_{\mathrm{TN}}$ ).

Soil potential N-mineralisation was measured before and after incubation. Subsamples were prepared for water saturation to determine moisture adjustments for each sample. The subsamples were placed in a funnel with Whatman no. 1 filter paper, wet with Milli-Q water and periodically rewet over a 2$\mathrm{h}$ period. They were then covered with cling film and drained for $2 \mathrm{~h}$, weighed and oven-dried at $105^{\circ} \mathrm{C}$ for $24 \mathrm{~h}$. They were reweighed, and moisture adjustments were calculated to $60 \%$ for each sample. For extractions, $5 \mathrm{~g}$ of moisture adjusted soil was put in an extraction bottle, covered with covered with polythene and incubated at $25^{\circ} \mathrm{C}$ for 14 days. A second sample was extracted immediately. The incubated and nonincubated subsamples were extracted using $\mathrm{KCl}(1 \mathrm{M})$, and the filtrate was analysed for inorganic $\mathrm{N}$ using an autoanalyzer (Elementar Vario EL III). Potential Nmineralisation was calculated as the difference in inorganic $\mathrm{N}$ before and after incubation.

\subsubsection{Phospholipid fatty acid analysis}

Phospholipid fatty acid (PLFA) analysis was used to determine the overall microbial community composition and dominance. Soil subsamples were taken from soils previously stored at -80 ${ }^{\circ} \mathrm{C}$ and extracted for PLFA determination by gas chromatography (Vestle and White 1989; Willers et al. 2015). Microbial PLFA markers were identified and measured as per the method by Frostegard et al. (2011) to estimate the total and group-specific microbial marker biomass. The i15:0, a15:0, i16:0, a17:0 and i17:0 PLFA markers were used as gram-

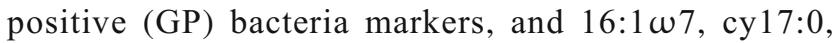
cis 18:1 $\omega 7$ and cy 19:0 as gram-negative (GN) bacteria markers. Total bacteria were estimated from the sum of GP and GN bacteria, and 15:0 marker mass. Total fungi were measured

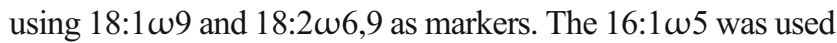
as a proxy measurement for arbuscular mycorrhizal (AM) fungi. Total PLFA expresses total microbial marker biomass and was estimated as the sum of total bacteria, total fungi, AM fungi

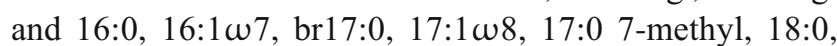
br18:0, 18:1 $\omega 5$ and 19:1 markers. The fungal:bacterial and GP:GN ratios were calculated by dividing the respective biomarker masses.

\subsection{Statistical analysis}

Data were evaluated using R (version 4.0) on the software RStudio (version 1.1.463). Since only water content and total $\mathrm{C}$ in unsealed soil presented data with a normal distribution according to the Shapiro-Wilk test, the non-parametric Wilcoxon test was applied. Where microbial attributes presented values equal to zero, they were considered null values (Table 1), whilst some soil samples did not present detectable amounts of PLFA during gas chromatography and so were excluded from the analysis. Boxplots were constructed using the ggplot package, and statistical significance was presented to compare sealed and unsealed soils. The correlations between soil properties and microbial attributes were estimated using the Spearman's rank correlation (ggcorrplot package).

\section{Results}

Sealed soils exhibited consistently lower values than unsealed soils across all measured soil properties and microbial attributes, other than the $\mathrm{C}: \mathrm{N}$ ratio (Table 1$)$. Total $\mathrm{C}(p=0.0026)$, total $\mathrm{N}(p<0.001)$, and water content $(p<0.001)$ were all significantly lower in sealed soil than unsealed soil (Fig. 2a, b, and $\mathrm{d})$, whilst the $\mathrm{C}: \mathrm{N}$ ratio $(p=0.023)$ was higher in sealed soil (Fig. 2c). All microbial attributes exhibited significantly lower values in sealed soil than unsealed soil: MBC, Nmineralisation, total PLFA, total fungi, AM fungi, total bacteria, GP bacteria and GN bacteria presented $p<0.001$; fungal:bacterial ratio presented $p=0.019$; and GP:GN bacterial ratio presented $p=0.0017$ (Figs. 3 and 4).

Significant correlations were observed between soil properties and microbial PLFA attributes; however, MBC and Nmineralisation potential showed no correlation with soil properties in this study (Table 2). In sealed soil, total bacteria had a strong and positive correlation with total $\mathrm{N}$ (rho $=0.63, p=$ 0.038 ) and water content ( $\mathrm{rho}=0.71, p=0.015)$, GP bacteria a strong and positive correlation with total $\mathrm{N}$ (rho $=0.63, \mathrm{p}=$ 0.038 ) and water content (rho $=0.71, p=0.015$ ), and GN bacteria a strong and positive correlation with total $\mathrm{C}$ (rho = $0.64, p=0.032$ ), total $\mathrm{N}$ (rho $=0.71, p=0.015$ ) and water content ( $\mathrm{rho}=0.79, \mathrm{p}=0.004$ ). In unsealed soil, total PLFA, total fungi, total bacteria and GP bacteria presented moderate to strong positive correlations with total $\mathrm{C}$ (rho $=0.58, p=$ 
Table 1 Descriptive statistics of soil properties and microbial attributes in sealed and unsealed soils

\begin{tabular}{|c|c|c|c|c|c|c|c|}
\hline Variable groups & Variables & Pavement types & $n$ & Null* & Min-max & Mean \pm SE & $\mathrm{CV}^{*}(\%)$ \\
\hline \multirow[t]{8}{*}{ Soil properties } & \multirow[t]{2}{*}{ Total $\mathrm{C} \mathrm{g} / \mathrm{Kg}$} & Sealed & 25 & 0 & $3.35-250.29$ & $49.78 \pm 10.67$ & 107.12 \\
\hline & & Unsealed & 25 & 0 & $14.02-128.49$ & $73.49 \pm 5.33$ & 36.27 \\
\hline & \multirow[t]{2}{*}{ Total N g/Kg } & Sealed & 25 & 0 & $0.39-13.75$ & $2.08 \pm 0.587$ & 141.03 \\
\hline & & Unsealed & 25 & 0 & $0.026-21.75$ & $5.36 \pm 0.79$ & 73.24 \\
\hline & \multirow[t]{2}{*}{$\mathrm{C}: \mathrm{N}$ ratio } & Sealed & 25 & 0 & $4.92-149.87$ & $35.81 \pm 7.13$ & 99.57 \\
\hline & & Unsealed & 25 & 0 & $5.91-27.49$ & $15.55 \pm 1.11$ & 35.62 \\
\hline & \multirow[t]{2}{*}{ Water content $\mathrm{g} / \mathrm{g}$} & Sealed & 25 & 0 & $0.09-0.74$ & $0.30 \pm 0.03$ & 54.09 \\
\hline & & Unsealed & 25 & 0 & $0.08-0.85$ & $0.47 \pm 0.03$ & 32.83 \\
\hline \multirow[t]{20}{*}{ Microbial attributes } & \multirow[t]{2}{*}{$\mathrm{MBC} \mathrm{g} / \mathrm{Kg}$} & Sealed & 25 & 7 & $0-47.85$ & $6.11 \pm 2.17$ & 177.67 \\
\hline & & Unsealed & 25 & 0 & $1.99-58.59$ & $19.79 \pm 3.04$ & 76.69 \\
\hline & \multirow[t]{2}{*}{ Mineralisation $\mathrm{g} / \mathrm{Kg}$} & Sealed & 25 & 12 & $0-2.87$ & $0.42 \pm 0.15$ & 178.14 \\
\hline & & Unsealed & 25 & 1 & $0-21.22$ & $5.61 \pm 1.03$ & 92.12 \\
\hline & \multirow[t]{2}{*}{ Total PLFA mg/Kg } & Sealed & 11 & 0 & $0.007-2.176$ & $0.311 \pm 0.198$ & 211.30 \\
\hline & & Unsealed & 16 & 0 & $0.338-2.996$ & $1.101 \pm 0.164$ & 59.61 \\
\hline & \multirow[t]{2}{*}{ Fungi $\mathrm{mg} / \mathrm{Kg}$} & Sealed & 11 & 3 & $0-0.239$ & $0.036 \pm 0.021$ & 197.03 \\
\hline & & Unsealed & 16 & 0 & $0.118-0.867$ & $0.357 \pm 0.050$ & 56.33 \\
\hline & \multirow[t]{2}{*}{ AM fungi $\mathrm{mg} / \mathrm{Kg}$} & Sealed & 11 & 8 & $0-0.019$ & $0.003 \pm 0.002$ & 230.69 \\
\hline & & Unsealed & 16 & 0 & $0.008-0.146$ & $0.062 \pm 0.009$ & 60.98 \\
\hline & \multirow[t]{2}{*}{ Bacteria $\mathrm{mg} / \mathrm{Kg}$} & Sealed & 11 & 5 & $0-0.832$ & $0.094 \pm 0.075$ & 263.19 \\
\hline & & Unsealed & 16 & 0 & $0.075-0.821$ & $0.304 \pm 0.045$ & 58.83 \\
\hline & \multirow[t]{2}{*}{ GP bacteria $\mathrm{mg} / \mathrm{Kg}$} & Sealed & 11 & 5 & $0-0.364$ & $0.043 \pm 0.033$ & 249.92 \\
\hline & & Unsealed & 16 & 0 & $0.044-0.572$ & $0.187 \pm 0.032$ & 68.37 \\
\hline & \multirow[t]{2}{*}{$\mathrm{GN}$ bacteria $\mathrm{mg} / \mathrm{Kg}$} & Sealed & 11 & 6 & $0-0.468$ & $0.050 \pm 0.042$ & 277.50 \\
\hline & & Unsealed & 16 & 0 & $0.031-0.236$ & $0.113 \pm 0.013$ & 45.08 \\
\hline & \multirow[t]{2}{*}{ Fungal:bacterial ratio } & Sealed & 10 & 4 & $0-2.470$ & $0.663 \pm 0.284$ & 135.20 \\
\hline & & Unsealed & 16 & 0 & $0.717-1.585$ & $1.206 \pm 0.062$ & 20.57 \\
\hline & \multirow[t]{2}{*}{ GP:GN bacterial ratio } & Sealed & 10 & 5 & $0-2.151$ & $0.628 \pm 0.237$ & 119.30 \\
\hline & & Unsealed & 16 & 0 & $0.958-2.428$ & $1.584 \pm 0.104$ & 26.16 \\
\hline
\end{tabular}

$n$ the number of values, null the number of null values, $\min$ the minimal value, $\max$ the maximal value, $S E$ the standard error of the mean, $C V$ the coefficient of variation

a

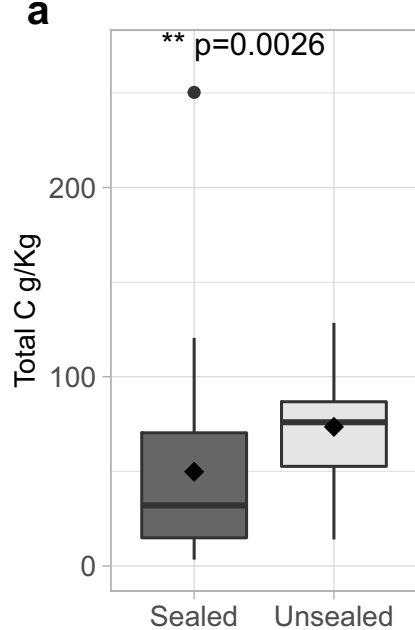

b

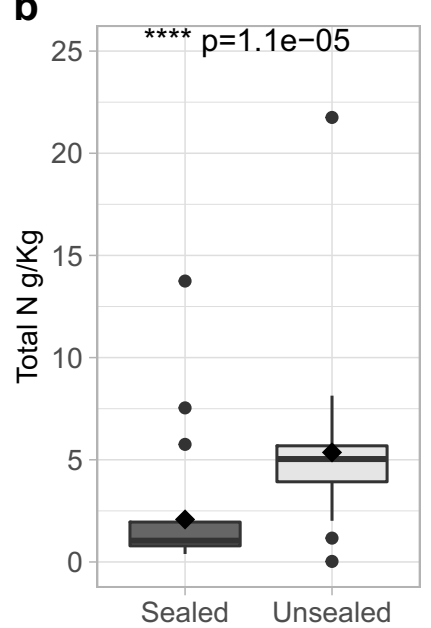

Fig. 2 Soil properties in sealed and unsealed soils. a Total C, b total N, c $\mathrm{C}: \mathrm{N}$ ratio and $\mathbf{d}$ water content. A significant difference between sealed and unsealed soils was estimated by Wilcoxon test, with “*****, “****,

C
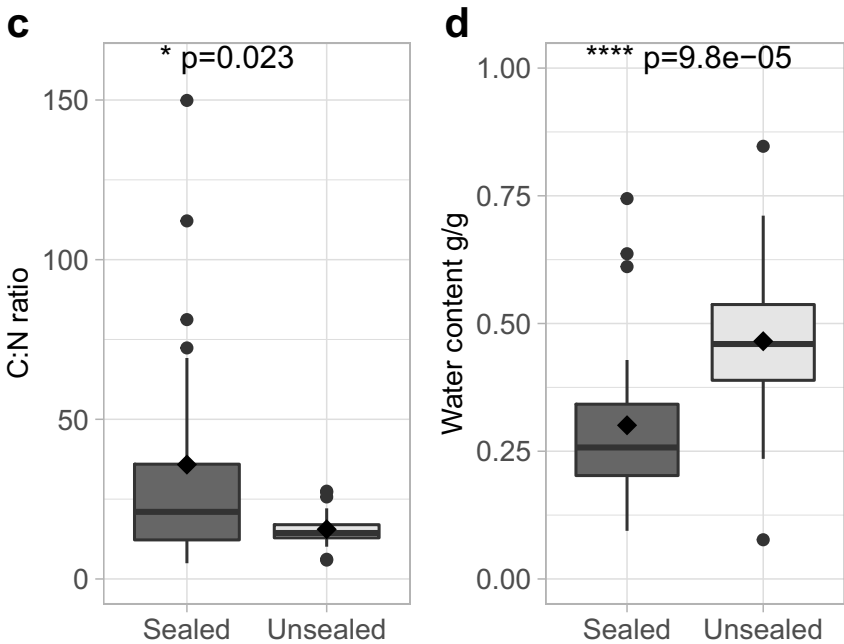

“**” and “*” indicating significance at $p<0.0001, p<0.001, p<0.01$ and $p<0.05$, respectively 

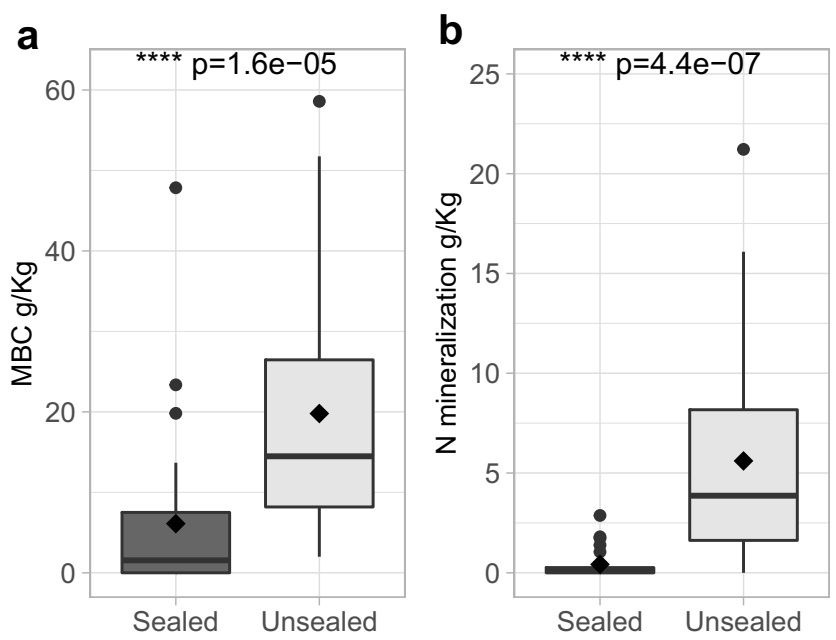

Fig. 3 Microbial biomass $\mathrm{C}(\mathrm{MBC})$ and $\mathrm{N}$-mineralisation potential in sealed and unsealed soils. A significant difference between sealed and unsealed soils was estimated by Wilcoxon test, with “*****" indicating significance at $p<0.0001$ a

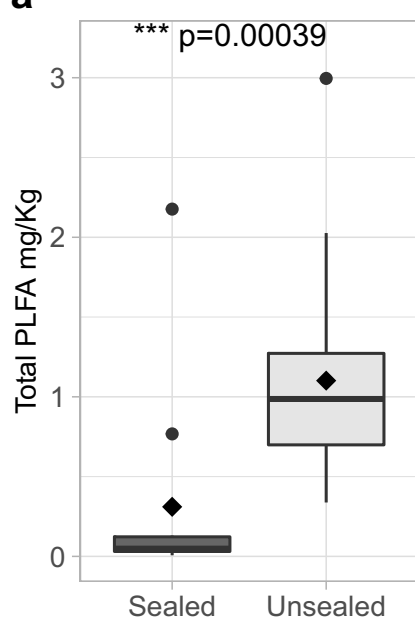

e

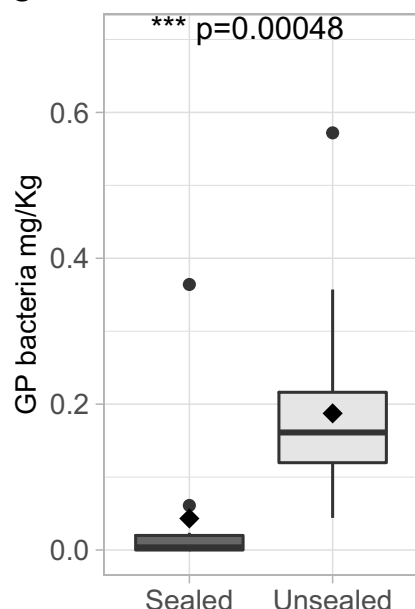

b

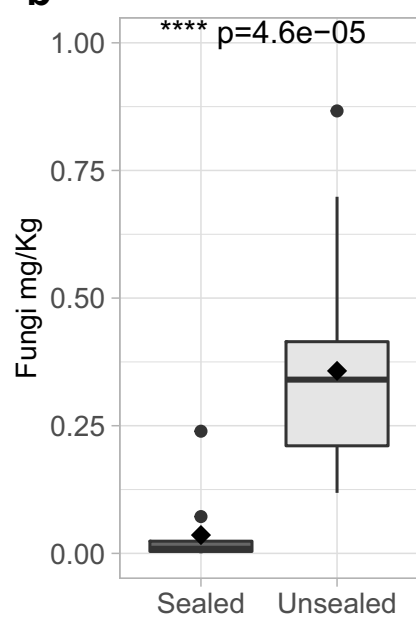

f

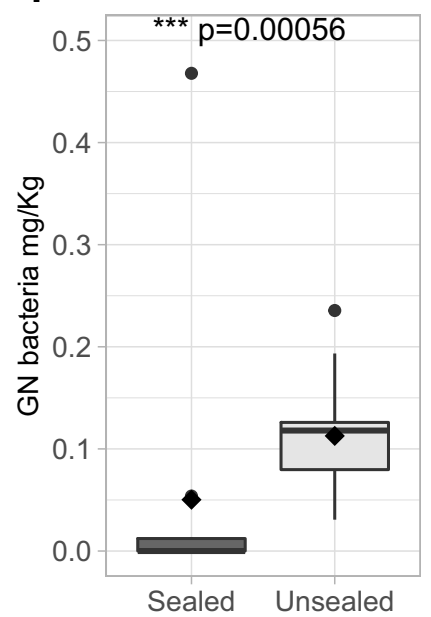

Fig. 4 Microbial community in sealed and unsealed soils. a Total PLFA, b total fungi, c AM fungi, $\mathbf{d}$ total bacteria, e GP bacteria, $\mathbf{f}$ GN bacteria, $\mathbf{g}$ fungal:bacteria ratio and $\mathbf{h}$ GP:GN bacterial ratio. A significant difference
$0.020 ;$ rho $=0.59, p=0.019 ;$ rho $=0.56, p=0.025$ and rho $=$ $0.52, p=0.042$, respectively); total $\mathrm{N}$ (rho $=0.62, p=0.012$; rho $=0.54, p=0.034$; rho $=0.68, p=0.005$; and rho $=0.69, p$ $=0.004$, respectively); and water content (rho $=0.75, p=$ $0.001 ;$ rho $=0.75, p=0.001 ;$ rho $=0.68, p=0.005$; and rho $=0.66, p=0.007$, respectively). GN bacteria had a strong positive correlation with total $\mathrm{N}$ (rho $=0.61, p=0.015$ ) and water content (rho $=0.65, p=0.008)$, and the GP:GN bacterial ratio showed a moderate positive correlation with total $\mathrm{C}$ (rho $=0.52, p=0.040$ ).

\section{Discussion}

In contrasting soil samples from sealed and unsealed areas, we observed that sealing affects soil properties, reduces the microbial community and limits microbial processes, changes which may disrupt important soil ecosystem services. Soil

C

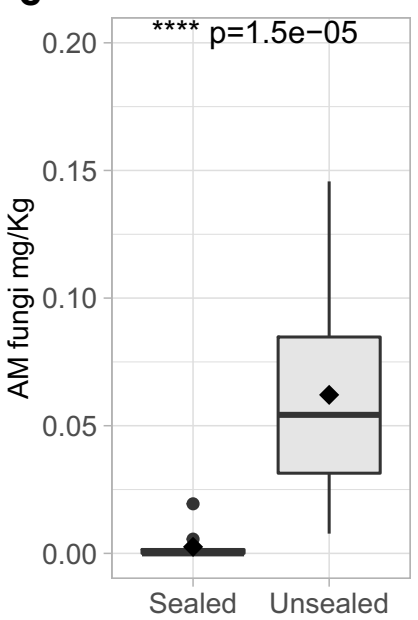

d

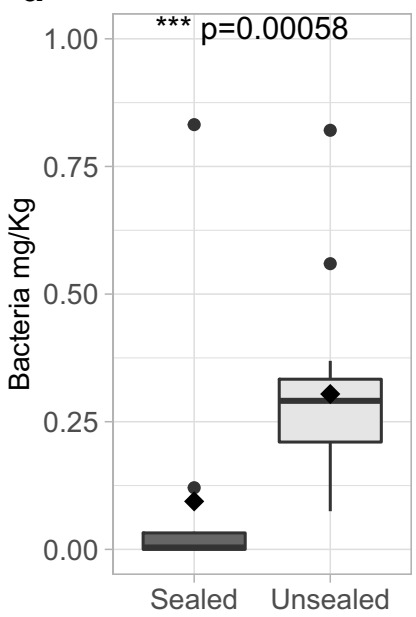

g

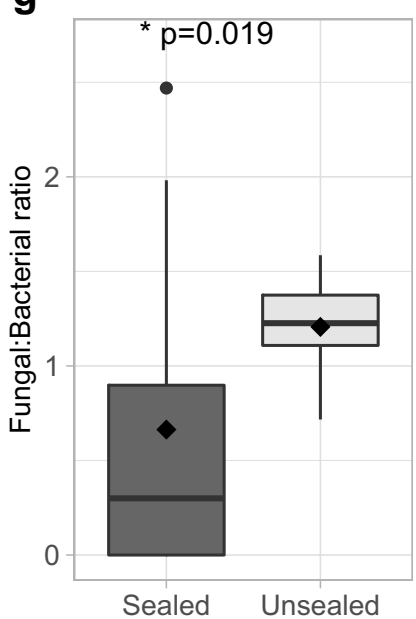

h

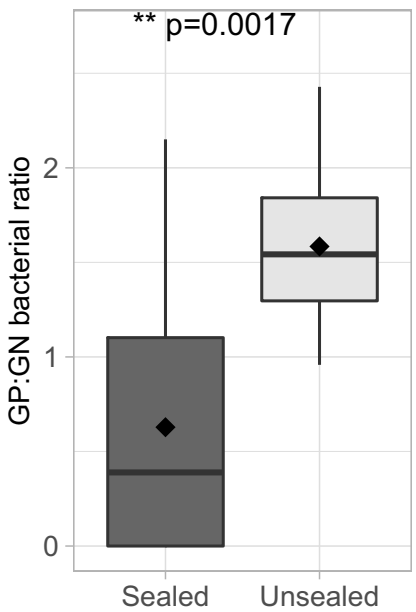

between sealed and unsealed soils was estimated by Wilcoxon test, with “****", "***" and "***" indicating significance at $p<0.0001, p<0.001$ and $p<0.01$, respectively 
Table 2 Spearman's rank correlation (rho) and $p$ values of correlations between microbial attributes and soil properties in sealed and unsealed soils. Significant correlations with $p$ values $<0.05$ are indicated in italics

\begin{tabular}{|c|c|c|c|c|c|c|c|c|c|}
\hline \multirow[t]{2}{*}{ Microbial attribute } & \multirow[t]{2}{*}{ Soil status } & \multicolumn{2}{|c|}{ Total C } & \multicolumn{2}{|c|}{ Total N } & \multicolumn{2}{|c|}{$\mathrm{C}: \mathrm{N}$ ratio } & \multicolumn{2}{|c|}{ Water content } \\
\hline & & rho & $p$ value & rho & $p$ value & rho & $p$ value & rho & $p$ value \\
\hline \multirow[t]{2}{*}{ MBC } & Sealed & 0.31 & 0.356 & 0.61 & 0.052 & -0.27 & 0.418 & 0.47 & 0.146 \\
\hline & Unsealed & 0.50 & 0.051 & 0.20 & 0.450 & 0.35 & 0.188 & 0.41 & 0.114 \\
\hline \multirow[t]{2}{*}{$\mathrm{N}$-mineralisation potential } & Sealed & -0.04 & 0.902 & -0.21 & 0.534 & 0.02 & 0.951 & -0.18 & 0.598 \\
\hline & Unsealed & 0.29 & 0.278 & 0.25 & 0.343 & 0.04 & 0.891 & -0.04 & 0.891 \\
\hline \multirow[t]{2}{*}{ Total PLFA } & Sealed & 0.57 & 0.071 & 0.55 & 0.082 & 0.13 & 0.714 & 0.55 & 0.087 \\
\hline & Unsealed & 0.58 & 0.020 & 0.62 & 0.012 & -0.08 & 0.771 & 0.75 & 0.001 \\
\hline \multirow[t]{2}{*}{ Total fungi } & Sealed & 0.46 & 0.156 & 0.5 & 0.113 & 0.03 & 0.936 & 0.5 & 0.121 \\
\hline & Unsealed & 0.59 & 0.019 & 0.54 & 0.034 & -0.01 & 0.978 & 0.75 & 0.001 \\
\hline \multirow[t]{2}{*}{ Total bacteria } & Sealed & 0.56 & 0.072 & 0.63 & 0.038 & -0.13 & 0.696 & 0.71 & 0.015 \\
\hline & Unsealed & 0.56 & 0.025 & 0.68 & 0.005 & -0.13 & 0.633 & 0.68 & 0.005 \\
\hline \multirow[t]{2}{*}{ Fungal:bacterial ratio } & Sealed & 0.23 & 0.499 & 0.09 & 0.802 & 0.19 & 0.574 & 0.23 & 0.499 \\
\hline & Unsealed & 0.29 & 0.283 & -0.22 & 0.404 & 0.48 & 0.064 & 0.03 & 0.926 \\
\hline \multirow[t]{2}{*}{ GP bacteria } & Sealed & 0.56 & 0.072 & 0.63 & 0.038 & -0.13 & 0.696 & 0.71 & 0.015 \\
\hline & Unsealed & 0.52 & 0.042 & 0.69 & 0.004 & -0.19 & 0.484 & 0.66 & 0.007 \\
\hline \multirow[t]{2}{*}{ GN bacteria } & Sealed & 0.64 & 0.032 & 0.71 & 0.015 & -0.19 & 0.569 & 0.79 & 0.004 \\
\hline & Unsealed & 0.21 & 0.443 & 0.61 & 0.015 & -0.42 & 0.104 & 0.65 & 0.008 \\
\hline \multirow[t]{2}{*}{ GP:GN bacterial ratio } & Sealed & 0.42 & 0.203 & 0.55 & 0.079 & -0.19 & 0.569 & 0.68 & 0.022 \\
\hline & Unsealed & 0.52 & 0.040 & 0.47 & 0.070 & 0.01 & 0.969 & 0.33 & 0.217 \\
\hline
\end{tabular}

properties were notably altered in sealed areas, with a reduction of total $\mathrm{C}$, total $\mathrm{N}$ and water content, and a consequent increase in C:N ratio. Sealing had a negative impact on microbial attributes, with a large reduction of the microbial community (MBC and PLFA biomarkers) and activity (Nmineralisation). Additionally, microbial attributes that correlated with soil properties in unsealed soil did not show equivalent correlations in sealed soil, such as those between total PLFA and total fungi to total $\mathrm{C}$, and total $\mathrm{N}$ and water content. These results suggest that the microbial community in sealed soil may respond differently to that in unsealed soil, indicating that sealing may disrupt the microbial response to changes in soil properties and lead to negative impacts on microbial services. The PLFA data provides an indicator of the microbial community in sealed soil, where low fungal:bacterial and gram-positive:gram-negative bacterial ratios indicate degradation in microbial $\mathrm{C}$ sequestration and a consequential effect on soil C storage in sealed soil.

\subsection{Soil sealing leads to depletion of $\mathrm{C}, \mathrm{N}$ and water content}

The sealed soils exhibited lower total $\mathrm{C}$, total $\mathrm{N}$ and water content than unsealed soils (Table 2 and Fig. 2a). Soil sealing leads to a reduction of soil $\mathrm{C}$ due to topsoil removal during the construction process and the reduction of $\mathrm{C}$ inputs from organic matter, plant root exudates and residue decomposition
(Edmondson et al. 2012; Raciti et al. 2012; Wei et al. 2013, 2014; Piotrowska-Długosz and Charzyński 2015; Yan et al. 2015; Majidzadeh et al. 2017, 2018). Indeed, sealed soils have been recorded as having significantly lower $\mathrm{C}$ stores when compared with unsealed or greenspace soils in urban areas (Wei et al. 2014; Piotrowska-Długosz and Charzyński 2015; Majidzadeh et al. 2017). Additionally, if $C$ decomposition continues within sealed soil, even at a low rate (Wei et al. 2014; Piotrowska-Długosz and Charzyński 2015), and there are negligible C inputs (Majidzadeh et al. 2018), this will contribute to $\mathrm{C}$ losses. In this context, elevation of microbial $\mathrm{C}$ respiration in sealed soil has been linked to increases in water content (Piotrowska-Długosz and Charzyński 2015; Majidzadeh et al. 2017, 2018). In sealed soil, water content is affected by the type and size of pavement or sealing surface (Morgenroth et al. 2013), and beneath impervious and semipermeable pavements, the water content is, in general, lower than in greenspace soils (Hu et al. 2018; Piotrowska-Długosz and Charzyński 2015). In soil under semi-permeable surfaces, water moving from adjacent greenspaces into sealed soil can promote $\mathrm{C}$ inputs beneath sealed surfaces (Majidzadeh et al. 2018); however, this can also increase the microbial processes of $\mathrm{C}$ decomposition and lead to $\mathrm{C}$ losses (Majidzadeh et al. 2017, 2018). In soil under house crawl spaces of different ages, most $\mathrm{C}$ was lost in the first 50 years after construction, but after 50 years, $\mathrm{C}$ sequestration became the dominant process (Majidzadeh et al. 2018). Overall, it is not clear whether 
longer periods of sealing lead to an increase or decrease in the $\mathrm{C}$ balance of sealed soils, and this is an area which requires further investigation.

The notable depletion of total N, as seen in our results (Fig. $2 b$ ), is a commonly observed consequence of soil sealing, often being greater in magnitude than losses of total or organic C (Raciti et al. 2012; Zhao et al. 2012; Wei et al. 2014; Majidzadeh et al. 2018; Hu et al. 2018). Our results indicate that, in sealed soil, total $\mathrm{N}$ was reduced by over $60 \%$ compared with unsealed soil (Fig. 2b), whilst total $\mathrm{C}$ was reduced by nearly $40 \%$ compared with unsealed soil (Fig. 2a), leading to a higher $\mathrm{C}: \mathrm{N}$ ratio in sealed soil (Fig. 2c). Our results are comparable to other observations of sealed soil where total $\mathrm{C}$ reduction was between 42 and $57 \%$, and $\mathrm{N}$ depletion was between 47 and 97\% (Majidzadeh et al. 2018; PiotrowskaDługosz and Charzyński 2015; Raciti et al. 2012; Zhao et al. 2012). The effect of sealing appears to be most notable and variable for $\mathrm{N}$ dynamics and processes which can be connected to the length of time sealed, organic $\mathrm{C}$ availability and water content, influencing the sealing impact on microbial processes (Zhao et al. 2012; Piotrowska-Długosz and Charzyński 2015; Majidzadeh et al. 2017, 2018) and Nmineralisation potential (Fig. 3b, Zhao et al. 2012). Previous research has shown that sufficient water content can promote microbial decomposition and $\mathrm{N}$-mineralisation where there is available organic C (Zhao et al. 2012; Majidzadeh et al. 2018), leading to inorganic N production (Zhao et al. 2012; Majidzadeh et al. 2018), and potential leaching of $\mathrm{NH}_{4}{ }^{+}-\mathrm{N}$ and $\mathrm{NO}_{3}{ }^{-} \mathrm{N}$ and accumulation in the subsoil (Zhao et al. 2012). Where water can infiltrate into sealed soils from adjacent unsealed areas (Majidzadeh et al. 2018), we speculate that mineralisation of remaining organic matter could be stimulated. Considering, the reduced levels of $\mathrm{C}$ and the absence of plant roots, $\mathrm{N}$ assimilation by microorganisms and plants is likely to be low, resulting in $\mathrm{N}$ losses over time by leaching, subsoil accumulation and groundwater transport. Beyond that, these circumstances may lead to inorganic $\mathrm{N}$ pollution of urban groundwater and water courses (Zhao et al. 2012).

\subsection{Sealing alters microbial attributes and community composition}

Soil sealing leads to a drastic reduction in microbial attributes. Our results showed that sealed soil exhibited a reduction in MBC (Fig. 3a), as consistently reported in previous studies (Wei et al. 2013; Piotrowska-Długosz and Charzyński 2015; Majidzadeh et al. 2017, 2018). Observations of low MBC in sealed soil have commonly been associated with low $\mathrm{C}, \mathrm{N}$ and water content (Wei et al. 2013; Piotrowska-Długosz and Charzyński 2015; Majidzadeh et al. 2017, 2018; Hu et al. 2018). Our PLFA data also demonstrated the negative impact of sealing on the microbial community (Fig. 3), with sealed soil exhibiting significantly lower mass of total PLFA and microbial markers, consistent with reductions in $\mathrm{MBC}$, total $\mathrm{C}$, total $\mathrm{N}$ and water content. It has been observed that a reduction in the microbial community reflects low microbial activity (Zhao et al. 2012; Piotrowska-Długosz and Charzyński 2015), a pattern also observed in our results with the significantly reduced $\mathrm{N}$-mineralisation potential in sealed soil.

In studies of urban soil, few have considered the relationship between soil properties and microbial attributes in both sealed and unsealed soil. Indeed, physical and chemical properties, in particular water content, have been shown to have significant effects on microbial attributes in unsealed soils (Wei et al. 2014; Piotrowska-Długosz and Charzyński 2015) and have exhibited positive correlations with $\mathrm{MBC}$, catalase activity and $\beta$-glucosidase activity in unsealed soil, but not in sealed soil (Piotrowska-Długosz and Charzyński 2015). Here, neither MBC nor N-mineralisation potential had significant correlations with any soil properties across sealed or unsealed soils. Conversely, the PLFA data does show significant responses of the microbial community to soil properties (Table 2). In unsealed soil, increases in $\mathrm{C}, \mathrm{N}$ and water content correlated with growth of the microbial community (total PLFA, bacteria and fungi), which is typical for natural soils or those under agricultural conservation management (Helgason et al. 2014; Bai et al. 2020). However, in sealed soil, only bacteria were correlated with soil properties, suggesting that sealing disrupts the relationships normally seen in natural and agricultural soils between microbial attributes and soil properties. Positive correlations identified between both total $\mathrm{N}$ and water content (Table 2) could indicate that input of water and $\mathrm{N}$ promoted bacterial growth. Other studies have found additional soil properties associated with sealing-driven microbial depletion, including potassium and phosphorus availability, heavy metals and dissolved organic $\mathrm{C}$ (Hu et al. 2018; Yu et al. 2019). Low respiration and metabolic quotient observed on sealed soil (Piotrowska-Długosz and Charzyński 2015) can suggest organic matter of low quality. Thus, sealing results in alterations to soil properties and negative impacts on the soil microbial community and processes.

Sealing also caused alterations to the microbial community composition, notably the fungal:bacterial ratio and GP:GN ratio. The effect of sealing was seen more strongly in fungi, with sealed soils having $~ 93 \%$ less fungi than unsealed soils, and $\sim 78 \%$ less bacteria than unsealed soils. Consequently, the fungal:bacterial ratio decreased in sealed soils indicating greater numbers of bacteria to fungi (Fig. 4g). Fungi have been shown to be resistant to conditions of low total N, high C:N ratio and low water content (Six et al. 2006; Strickland and Rousk 2010; Fang et al. 2020), conditions which are commonly observed in sealed soils. However, these conditions did not lead to greater dominance of fungi in this study. Conversely, soils affected by degradation processes such as tillage, deforestation, trampling and contamination usually present a greater impact on the fungal community and show 
a proportional decrease on the fungal:bacterial ratio (Kaur et al. 2005; Malmivaara-Lämsä et al. 2008; Simmons and Coleman 2008; Bischoff et al. 2016; Montiel-Rozas et al. 2018; Lopes and Fernandes 2020). Thus, our results suggest that fungi in sealed soils may be more affected by aspects of soil sealing not included in this study but that commonly arise due to the degradation processes of urbanisation, such as contamination and disturbance.

The decrease in the GP:GN bacterial ratio in sealed soil (Fig. 4h) suggests that GN bacteria are more adapted to sealing than GP bacteria. GN bacteria presented a positive correlation with total $\mathrm{C}$, whilst GP bacteria had no correlation with total C (Table 2). As GN bacteria are more dependent on simple sugars (Kramer and Gleixner 2008; Fanin et al. 2019), the organic $\mathrm{C}$ that is promoting GN bacterial growth is likely to be labile and soluble $\mathrm{C}$ transported by water from adjacent greenspaces, a process which has been suggested as a source of organic $\mathrm{C}$ in soils beneath house crawl spaces (Majidzadeh et al. 2018). Additionally, GN and GP bacteria had positive correlations with total $\mathrm{N}$ and water content, suggesting there may also be transport of soluble $\mathrm{N}$ by water from adjacent greenspaces, and that this may be an important source of nutrients for bacteria in sealed soil.

In contrast to GN bacteria, GP bacteria are linked to more complex SOC (Kramer and Gleixner 2008; Fanin et al. 2019). Therefore, the low biomass of GP bacteria can be related to low levels of complex SOC remaining in sealed soil as a consequence of topsoil removal and microbial degradation over time.

\subsection{Sealing limits the microbial community and affects the $\mathrm{C}$ storage service}

Litter degradation plays an important role in $\mathrm{C}$ inputs into soil. Organic and inorganic compounds released during decomposition, and the remaining complex organic compounds are essential components of soil organic matter synthesis (Jastrow et al. 2007). In sealed soil, the sealed surface acts as a barrier preventing this source of organic $\mathrm{C}$ from reaching the soil, such that low or no organic $\mathrm{C}$ or nutrients from litter can enter the soil (Zhao et al. 2012; Majidzadeh et al. 2017, 2018), which in turn, affect soil biological and nutrient processes.

Plants and roots also contribute greatly to soil $\mathrm{C}$ stores. The lack of plants growing on sealed surfaces usually leads to a reduced root colonisation, limiting the $\mathrm{C}$ inputs from plant exudates and dead roots. Consequently, microbial processes that take place in the soil-root zone and depend on plant exudates are limited beneath sealed surfaces. Many of these processes are related to $\mathrm{N}$ inputs and nutrient availability, highlighting $\mathrm{N}$ biological fixation, $\mathrm{N}$ oxidation reactions and phosphate solubility (Sylvia et al. 2005; Paul 2007). Many fungal species establish a mutualistic association with plant roots to obtain organic molecules and, as payment, they colonise soil space to assimilate and transport nutrients directly back to the plant roots (Smith and Read 2008). By enhancing the soil microbial community, roots enable microbial processes connected with organic matter formation, such as the microbial release of biomolecules and dead biomass (Jastrow et al. 2007; Clemmensen et al. 2013). Thus, it is likely that the lack of plant and root growth, litter inputs and microbial activity in the soil-root zone all contribute to the lower $\mathrm{C}$ stores in sealed soil.

Fungal biomass in soil is, in general, suggested to contribute to high soil C storage (Strickland and Rousk 2010). Fungi exhibit low nutrient requirements and high $\mathrm{C}$ use efficiency which results in more $\mathrm{C}$ being allocated to their biomass, per unit of substrate used, compared with bacteria, which have lower $\mathrm{C}$ use efficiency (Six et al. 2006). Fungi have the ability to grow under a high $\mathrm{C}: \mathrm{N}$ ratio, permitting their mycelial growth to explore wider areas and translocate nutrients across the soil (Strickland and Rousk 2010). In addition, fungal biomass is more complex and resistant to decomposition than bacterial biomass, introducing a more stable form of organic C in the soil (Jastrow et al. 2007; Clemmensen et al. 2013). Whilst studies have presented different insights into the functional implications of the fungal:bacterial ratio (Strickland and Rousk 2010; Soares and Rousk 2019), in general, a higher fungal:bacterial ratio is assumed to promote an increase in soil organic matter (Jastrow et al. 2007; Strickland and Rousk 2010). Therefore, the observed reduction in fungi and consequent bacterial dominance in sealed soil is likely to lead to notable limitations to $\mathrm{C}$ storage.

The lower GP:GN bacteria ratio in sealed soil illustrates that there is more GN bacteria to GP. This indicates that there is less recalcitrant $\mathrm{C}$ in the sealed soil (Kramer and Gleixner 2008; Fanin et al. 2019), which suggests the reduced ability of sealed soils not only to store $\mathrm{C}$ but to store it as stable $\mathrm{C}$ that may be more protected from decomposition (Lal 2004; Marschner et al. 2008), highlighting the wider impacts of soil sealing on the ecosystem service of soil C storage.

\section{Conclusion}

Soil properties were notably affected in sealed soil, with a large significant reduction in total $\mathrm{C}$, total $\mathrm{N}$ and water content in sealed soils. Microbial biomass $\mathrm{C}, \mathrm{N}$-mineralisation potential and microbial PLFA markers were also significantly reduced in sealed soils. Our results show that changes to soil properties, caused by sealing, led to a drastic decrease in the microbial community and important microbial processes. The increase of the C:N ratio and decrease of the F:B and GP:GN ratios suggest that sealed soils are degraded due to the loss of $\mathrm{C}$, which limits fungal and bacterial growth. In addition, the reduced inputs of $\mathrm{C}$ from litter degradation and plant exudates, associated with the reduction of fungal dominance, indicate a 
limitation on the $\mathrm{C}$ storage potential of sealed soil. Furthermore, the correlation of bacteria with $\mathrm{C}, \mathrm{N}$ and water suggests that there may transport of soluble $\mathrm{C}$ and $\mathrm{N}$ by water into sealed soils from adjacent greenspaces. This may be an important source of nutrients for microbes in sealed soil, and the investigation of this process would be beneficial to further understand sealed soil nutrient cycling and implications for $\mathrm{C}$ and $\mathrm{N}$ fluxes. In this context, further work, such chronosequence studies, would elucidate how urbanisation and soil sealing impact the dynamics of $\mathrm{C}$ and $\mathrm{N}$ and microbial processes over time, and as a consequence, the ecosystem services of sealed soil.

Authors contribution All authors contributed to the study conception and design. Material preparation, data collection and analysis were performed by Carly Stevens and Marlon Correa Pereira. The final draft of the manuscript was written by authors Marlon Correa Pereira and Roisin O'Riordan, and all authors contributed to previous versions of the manuscript. All authors read and approved the final manuscript.

Funding This study was funded by the Faculty of Science and Technology, Lancaster University, UK. The author Roisin O'Riordan was also supported by the Soil-Value project funded by the UKRI Engineering and Physical Sciences Research Council, Living With Environmental Change Challenge Fellowships (grant number EP/ N030532/1).

Data availability All authors ensure that all data and materials as well as software application or custom code support their published claims and comply with field standards.

\section{Compliance with ethical standards}

Conflict of interest The authors declare that they have no conflict of interest.

\section{Ethics approval and consent to participate Not applicable.}

Consent for publication The authors have no financial or proprietary interests in any material discussed in this article and consent to publish the manuscript.

Code availability All authors ensure that software application or custom code support their published claims and comply with field standards.

Open Access This article is licensed under a Creative Commons Attribution 4.0 International License, which permits use, sharing, adaptation, distribution and reproduction in any medium or format, as long as you give appropriate credit to the original author(s) and the source, provide a link to the Creative Commons licence, and indicate if changes were made. The images or other third party material in this article are included in the article's Creative Commons licence, unless indicated otherwise in a credit line to the material. If material is not included in the article's Creative Commons licence and your intended use is not permitted by statutory regulation or exceeds the permitted use, you will need to obtain permission directly from the copyright holder. To view a copy of this licence, visit http://creativecommons.org/licenses/by/4.0/.

\section{References}

Bai Y, Zha X, Chen S (2020) Effects of the vegetation restoration years on soil microbial community composition and biomass in degraded lands in Changting County, China. J For Res 28:1-14

Bischoff N, Mikutta R, Shibistova O, Puzanov A, Reichert E, Silanteva M, Grebennikova A, Schaarschmidt F, Heinicke S, Guggenberger G (2016) Land-use change under different climatic conditions: consequences for organic matter and microbial communities in Siberian steppe soils. Agric Ecosyst Environ 235:253-264

Bradley RI, Milne R, Bell J, Lilly A, Jordan C, Higgins A (2005) A soil carbon and land use database for the United Kingdom. Soil Use Manage 21(4):363-369

Brookes PC, Landman A, Pruden G, Jenkinson DS (1985) Chloroform fumigation and the release of soil nitrogen: a rapid direct extraction method to measure microbial biomass nitrogen in soil. Soil Biol Biochem 17(6):837-842

Chen Y, Wang X, Jiang B, Yang N, Li L (2016) Pavement induced soil warming accelerates leaf budburst of ash trees. Urban For Urban Green 16:36-42

Chen Y, Wang X, Jiang B, Wen Z, Yang N, Li L (2017) Tree survival and growth are impacted by increased surface temperature on paved land. Landsc Urban Plan 162:68-79

Clemmensen KE, Bahr A, Ovaskainen O, Dahlberg A, Ekblad A, Wallander H, Stenlid J, Finlay RD, Wardle DA, Lindahl BD (2013) Roots and associated fungi drive long-term carbon sequestration in boreal forest. Science 339(6127):1615-1618

Edmondson JL, Davies ZG, McHugh N, Gaston KJ, Leake JR (2012) Organic carbon hidden in urban ecosystems. Sci Rep 2:963

Fang X, Zhou G, Qu C, Huang W, Zhang D, Li Y, Yi Z, Liu J (2020) Translocating subtropical forest soils to a warmer region alters microbial communities and increases the decomposition of mineralassociated organic carbon. Soil Biol Biochem 142:107707

Fanin N, Kardol P, Farrell M, Nilsson MC, Gundale MJ, Wardle DA (2019) The ratio of gram-positive to gram-negative bacterial PLFA markers as an indicator of carbon availability in organic soils. Soil Biol Biochem 128:111-114

Fini A, Frangi P, Mori J, Donzelli D, Ferrini F (2017) Nature based solutions to mitigate soil sealing in urban areas: results from a 4year study comparing permeable, porous, and impermeable pavements. Environ Res 156:443-454

Frostegård Å, Tunlid A, Bååth E (2011) Use and misuse of PLFA measurements in soils. Soil Biol Biochem 43(8):1621-1625

Helgason BL, Konschuh HJ, Bedard-Haughn A, VandenBygaart AJ (2014) Microbial distribution in an eroded landscape:buried A horizons support abundant and unique communities. Agric Ecosyst Environ 196:94-102

Hu Y, Dou X, Li J, Li F (2018) Impervious surfaces alter soil bacterial communities in urban areas: a case study in Beijing, China. Front Microbiol 9:226

Hu S, Fan Y, Zhang T (2020) Assessing the effect of land use change on surface runoff in a rapidly urbanized city: a case study of the central area of Beijing. Land 9(1):17

Jastrow JD, Amonette JE, Bailey VL (2007) Mechanisms controlling soil carbon turnover and their potential application for enhancing carbon sequestration. Clim Change 80(1-2):5-23

Kaur A, Chaudhary A, Kaur A, Choudhary R, Kaushik R (2005) Phospholipid fatty acid-a bioindicator of environment monitoring and assessment in soil ecosystem. Curr Sci 10:1103-1112

Kelleher C, Golden HE, Burkholder S, Shuster W (2020) Urban vacant lands impart hydrological benefits across city landscapes. Nat Commun 11(1):1-11

Kramer C, Gleixner G (2008) Soil organic matter in soil depth profiles: distinct carbon preferences of microbial groups during carbon transformation. Soil Biol Biochem 40(2):425-433 
Lal R (2004) Soil carbon sequestration to mitigate climate change. Geoderma 123:1-22

Li Y, Liu M, Li R, Sun P, Xia H, He T (2020) Polycyclic aromatic hydrocarbons in the soils of the Yangtze River Delta Urban Agglomeration, China: influence of land cover types and urbanization. Sci Total Environ 715:137011

Lopes LD, Fernandes MF (2020) Changes in microbial community structure and physiological profile in a kaolinitic tropical soil under different conservation agricultural practices. Appl Soil Ecol 152: 103545

Marschner B, Brodowski S, Dreves A, Gleixner G, Gude A, Grootes PM, Hamer U, Heim A, Jandl G, Ji R, Kaiser K, Kalbitz K, Kramer C, Leinweber P, Rethemeyer J, Schäffer A, Schmidt MWI, Schwark L, Wiesenberg GLB (2008) How relevant is recalcitrance for the stabilization of organic matter in soils? J Plant Nutr Soil Sci 171(1):91110

Majidzadeh H, Lockaby BG, Governo R (2017) Effect of home construction on soil carbon storage-a chronosequence case study. Environ Pollut 226:317-323

Majidzadeh H, Lockaby BG, Price R, Governo R (2018) Soil carbon and nitrogen dynamics beneath impervious surfaces. Soil Sci Soc Am J 82(3):663-670

Malmivaara-Lämsä M, Hamberg L, Haapamäki E, Liski J, Kotze DJ, Lehvävirta S, Fritze H (2008) Edge effects and trampling in boreal urban forest fragments-impacts on the soil microbial community. Soil Biol Biochem 40(7):1612-1621

Montiel-Rozas MM, Domínguez MT, Madejón E, Madejón P, Pastorelli R, Renella G (2018) Long-term effects of organic amendments on bacterial and fungal communities in a degraded Mediterranean soil. Geoderma 332:20-28

Morgenroth J, Buchan G, Scharenbroch BC (2013) Belowground effects of porous pavements - soil moisture and chemical properties. Ecol Eng 51:221-228

Paul EA (2007) Soil microbiology, ecology, and biochemistry in perspective. Academic Press, Oxford

Piotrowska-Długosz A, Charzyński P (2015) The impact of the soil sealing degree on microbial biomass, enzymatic activity, and physicochemical properties in the Ekranic Technosols of Torun (Poland). J Soils Sediments 15(1):47-59

Raciti SM, Hutyra LR, Finzi AC (2012) Depleted soil carbon and nitrogen pools beneath impervious surfaces. Environ Pollut 164:248-251

Simmons BL, Coleman DC (2008) Microbial community response to transition from conventional to conservation tillage in cotton fields. Appl Soil Ecol 40(3):518-528

Six J, Frey SD, Thiet RK, Batten KM (2006) Bacterial and fungal contributions to carbon sequestration in agroecosystems. Soil Sci Soc Am J 70(2):555-569

Smith SE, Read DJ (2008) Mycorrhizal symbiosis. Academic Press, New York
Soares M, Rousk J (2019) Microbial growth and carbon use efficiency in soil: links to fungal-bacterial dominance, SOC-quality and stoichiometry. Soil Biol Biochem 131:195-205

Strickland MS, Rousk J (2010) Considering fungal: bacterial dominance in soils-methods, controls, and ecosystem implications. Soil Biol Biochem 42(9): 1385-1395

Sylvia DM, Fuhrmann JJ, Hartel PG, Zuberer DA (2005) Principles and applications of soil microbiology. Pearson Prentice Hall, New Jersey

Vance ED, Brookes PC, Jenkinson DS (1987) An extraction method for measuring soil microbial biomass C. Soil Biol Biochem 19(6):703707

Vasenev VI, Stoorvogel JJ, Leemans R, Valentini R, Hajiaghayeva RA (2018) Projection of urban expansion and related changes in soil carbon stocks in the Moscow Region. J Clean Prod 170:902-914

Vestle J, White D (1989) Lipid analysis in microbial ecology-quantitative approaches to the study of microbial communities. Bioscience 39: $535-541$

Wei Z, Wu S, Zhou S, Lin C (2013) Installation of impervious surface in urban areas affects microbial biomass, activity (potential C mineralisation), and functional diversity of the fine earth. Soil Res 51(1):59-67

Wei ZQ, Wu SH, Zhou SL, Li JT, Zhao QG (2014) Soil organic carbon transformation and related properties in urban soil under impervious surfaces. Pedosphere 24(1):56-64

Willers C, Jansen van Rensburg PJ, Claassens S (2015) Phospholipid fatty acid profiling of microbial communities-a review of interpretations and recent applications. J Appl Microbiol 119(5):1207-1218

Wu X, Hu D, Ma S, Zhang X, Guo Z, Gaston KJ (2016) Elevated soil $\mathrm{CO}_{2}$ efflux at the boundaries between impervious surfaces and urban greenspaces. Atmos Environ 141:375-378

Yan Y, Kuang W, Zhang C, Chen C (2015) Impacts of impervious surface expansion on soil organic carbon-a spatially explicit study. Sci Rep 5:17905

Yan Y, Zhang C, Hu Y, Kuang W (2016) Urban land-cover change and its impact on the ecosystem carbon storage in a dryland city. Remote Sens 8(1):6

Yu W, Hu Y, Cui B, Chen Y, Wang X (2019) The effects of pavement types on soil bacterial communities across different depths. Int J Environ Res Public Health 16(10):1805

Zhao D, Li F, Wang R, Yang Q, Ni H (2012) Effect of soil sealing on the microbial biomass, $\mathrm{N}$ transformation and related enzyme activities at various depths of soils in urban area of Beijing, China. J Soils Sediments 12(4):519-530

Ziter C, Turner MG (2018) Current and historical land use influence soilbased ecosystem services in an urban landscape. Ecol Appl 28(3): 643-654

Publisher's note Springer Nature remains neutral with regard to jurisdictional claims in published maps and institutional affiliations. 